\title{
Immobility and the re-imaginings of ethnic identity among Mongolian Kazakhs in the 21st century
}

\author{
Holly R. Barcus ${ }^{\mathrm{a}, *}$, Cynthia Werner ${ }^{\mathrm{b}}$ \\ a Macalester College, Geography Department, 1600 Grand Avenue, Saint Paul, MN 55105, United States \\ ${ }^{\mathrm{b}}$ Texas AEM University, College Station, TX 77843, United States
}

\section{A R T I C L E I N F O}

\section{Article history:}

Received 12 July 2014

Received in revised form 2 December 2014

Available online 7 January 2015

\section{Keywords:}

Narrative identity

Homeland

Migration

Place identity

Mongolia

Immobility

\begin{abstract}
A B S T R A C T
Accompanying the dissolution of the USSR and the formation of new nation states in the 1990s, nearly half of Mongolian Kazakhs migrated from their adopted home of Mongolia to the imagined homeland of Kazakhstan. By 2000, a sizable percentage returned to Mongolia. In explaining their decisions to stay in or to return to Mongolia, the Kazakhs we interviewed cite several culturally specific factors. Place identities, as expressed through cultural elements of religiosity, kinship ties, and language versatility, tie Mongolian Kazakhs strongly to western Mongolia while meta-narratives about diaspora and homeland prescribe identity with Kazakhstan. Utilizing life history interviews, participant observation, and questionnaire data we argue that Mongolian Kazakhs actively employ narratives of their cultural history to re-create and re-establish place identities in Mongolia and ultimately re-imagine Mongolian-Kazakh community and identity. These recreated place identities have emerged among Mongolian-Kazakhs who chose to remain immobile or return migrated from the 'homeland' of Kazakhstan.
\end{abstract}

(c) 2014 Elsevier Ltd. All rights reserved.

\section{'Menin zherim-tugan zherim'}

$\sim$ A Kazakh proverb translated is 'my only land is my birth land'

\section{Introduction: Homelands, nation-building and ethnic return migration}

The early 1990s witnessed the dissolution of the USSR followed closely by the territorialization of the Former Soviet Union (FSU). In the fervor surrounding independence, each of the former republics in turn embarked on their own nation-building quest seeking to (re)create and instill a new, non-Russian, national identity. The process of building national identities in Kazakhstan took familiar forms of promoting Kazakh culture and language and through public education (Kuşçu, 2013). The project of nationalism and national identity in Kazakhstan, however, also included significant and extensive repatriation incentives and policies developed for the purpose of increasing the proportion of co-ethnics in what was in 1990 a nation where ethnic Kazakhs just barely outnumbered ethnic Russians (Diener, 2009; Kuşçu Bonnenfant, 2012).

\footnotetext{
* Corresponding author.

E-mail addresses: barcus@macalester.edu (H.R. Barcus), werner@tamu.edu (C. Werner).
}

Between 1992 and 2012, the repatriation program assisted approximately 944 thousand ethnic return migrants, known locally as oralman (Lillis, 2014).

Repatriation policies promoted the notion of 'homeland' and President Nazarbayev enthusiastically welcomed "home" his 'Kazakh kin', offering migration, employment, education, and financial incentives to ethnic Kazakhs living outside of the Kazakhstan territory (Kuşçu Bonnenfant, 2012). The widespread Kazakh diaspora heeded this call, migrating from Uzbekistan, Russia, China, Mongolia and elsewhere seeking to return to the "traditional Kazakh homeland'. From the state perspective, repatriation successfully 'returned' ethnic Kazakhs, tipping the balance of ethnic groups to favor a Kazakh majority by the late 1990s (Kuşçu, 2013).

Such ethnically privileged migration flows are created and codified by emerging nation-states for the purpose of increasing ethnic status thereby encouraging 'return' migration to the homeland. But for many who imagine the homeland as a panacea of acceptance and 'return' to an ethnically homogeneous territory, the reality of 'return' is often fraught with disappointment. While the conflation of ethnic, territorial, and national identities is politically efficient at the national policy scale, '...the privileged status of ethnic return migrants as co-ethnics often does not lead to the expected social payoff' (Tsuda, 2009, 325). Diener, describing the situation of ethnic Kazakhs in Kazakhstan writes '[i]t should ... be noted that few [co-ethnics] have been able to reconcile their sense of local territo- 
rialization with the socio-political changes occurring at the state scale. . the notion of Kazakhstani (civic national) territorial identity has yet to penetrate very deeply among the majority of peoples of the state. They continue to regard their ethnic identities as primary with the abstract notion of 'Kazakhstani' citizenship taking a subsidiary position' (Diener, 2006, 201). 'Civic national' identity, as a carry-over of Soviet 'internationalism', continues to have some importance, yet as in the Soviet past, the state-level discourse in support of a multi-ethnic state conceals a reality where one particular ethnic group experiences greater privileges (Schatz, 2000). During the Soviet period Russians were the privileged group while in post-Soviet context Schatz argues that Kazakhs are the privileged ethnic group. Thus 'internationalism' '... offer[s] a normatively appealing discourse to its non-titular population and a diffuse and ill-defined set of privileges to titular Kazakhs' (2000, 491 ). The privileging of one group over another, however, is dependent upon the construction of that group, in this case, the Kazakhs as an ethnic group, as one that prescribes or invites membership based on a set of predetermined practices or characteristics. Brubaker warns us of the dangers of such 'groupism' in our treatment of ethnic groups, reminding us that a label tends to create boundaries around groups suggestive of a level of internal homogeneity which is unlikely to exist (Brubaker, 2002, 164). Previous scholars, for example, have noted how the Kazakh identity is further complicated by sub-ethnic 'clan' identities, regional identities, adherence to cultural traditions, linguistic orientations, and religiosity (Davé, 2007; Diener, 2014; Koch, 2014; Schatz, 2004; Schwab, 2011). In the building of the new Kazakhstan nation-state, the promotion of homeland' narratives and post-Soviet 'internationalism' in principle privilege ethnic return migrants but in practice, as Diener notes, the outcomes are more complex. The repatriation program thus adds another layer of heterogeneity to the Kazakh identity as repatriated Kazakhs (oralman) are socially constructed as an internal 'Other' to native-born Kazakhs.

The construction of homelands and appeal to ethnic minority diasporas inspires the creation of an imagined homeland where a minority is welcomed as a majority member. Kaiser et al. suggest that 'homeland-making is defined as the efforts by the titular elites of these republics to construct ethnically stratified networks of social interaction that privilege members of the titular group over all others living in the republic' (Kaiser, 2000, Executive Summary). Indeed many ethnic return migrants find themselves discriminated against in their 'homeland'. Tsuda writes that 'not only is their ethnicity the reason that they return to the ancestral homeland, but it is also ironically the basis for their social exclusion as immigrants' (Tsuda, 2009, 325). The expected social and economic benefits of returning to the homeland thus fail to materialize prompting the choice for these "return" ethnic migrants of remaining in their 'homeland' or returning to their place of origin. Such movement prompted the question by Diener of 'one homeland or two?'. Those who remain in the origin face the question of whether to 'return' or remain in place (immobile).

Beginning in the early 1990s, following the opening of borders across Central Asia, a sizable portion of the Kazakh minority population in western Mongolia migrated to Kazakhstan. The rationale for leaving was clear - the loss of a central trading partner, Russia, coupled with the dismantling of the socialist economy, left herders and others in Mongolia without access to basic food staples and limited means of economic livelihood. While out-migration was not surprising, the magnitude of return migration by the end of the decade was unexpected. Sources estimate that up to one-third of the repatriated Kazakhs returned to Mongolia (Diener, 2009; Finke, 1999). Flows between the two countries evolved from a uni-directional flow out of western Mongolia to a lively exchange of migrants between Bayan-Ulgii and Kazakhstan (see Werner and Barcus, 2009; Barcus and Werner, 2010). Instead of losing its population, the province of Bayan-Ulgii, the home of nearly eighty-seven percent of the Mongolian Kazakh population in 1989 , has become a significant trading post along the western land route between China and Russia, with international flights connecting it directly to Kazakhstan. Like many areas of Mongolia, the region has also experienced the growth of foreign mining operations and international tourism. But Bayan-Ulgii of the 1990s was an impoverished region with a sizeable out-flow of ethnic Kazakhs and limited economic infrastructure. So why did so many Kazakh migrants return to Mongolia and why are many choosing not to migrate?

In this article we argue that faced with such discouraging outcomes for 'return' migrants to the Kazakh 'homeland', some Mongolian-Kazakhs choose to remain immobile, remaining in or returning to Mongolia rather than migrating permanently to the 'Kazakh homeland', despite significant repatriation incentives. ${ }^{1}$ We argue specifically that the production of narrative identities assert a particular, re-imagined, place-based Mongolian-Kazakh territorial identity which rewards immobility. On the one hand one could view these cultural elements as a reassertion of pre-Socialist Kazakh traditions, however, we argue that those who embrace these cultural elements are choosing to belong to a particular narrative identity of Kazakhness that is particular to Bayan-Ulgii. Following Brubaker's (2002) note of caution we further argue that rather than viewing themselves as part of a homogeneous 'Kazakh' identity, ethnic Kazakhs from Mongolia who choose to reside in Mongolia have re-imagined their Kazakh identity based on cultural elements specific to the territory of western Mongolia. We utilize the phrase 'Mongolian-Kazakh' to convey this territorially and culturally-based re-imagining of identity amongst this group.

We identify three forms of place-based attachments that create and assert a particular Mongolian-Kazakh identity and foster a sense of belonging missing for many who did not feel at home in Kazakhstan. These place specific attachments help form a narrative of Mongolian-Kazakhness, asserting a particular territorial identity, which influences the decision to remain (immobile) in Mongolia or to return to Mongolia following a previous migration to Kazakhstan. The re-emergence of cultural practices suppressed during the socialist period, combined with disappointing reception in Kazakhstan, has encouraged the development of these place specific identities and fostered a sense of Kazakh belonging that is simultaneously unique to western Mongolia, while capturing the essence of historical imaginings of 'Kazakhness'.

\section{Identity and the deterritorialized nation}

In the introduction to their book "State/Nation/Transnation", Willis et al. state that '[I]f the concept of 'nation' is decoupled from 'state', then the spatial fixity of the concept is often erased, as 'peoples' can form 'nations' without occupying the same territory' $(2004,3)$. Non-territorially-based grouping of peoples have also been termed 'diasporas' (Cohen, 1997), 'transnational kinship groups' (Faist, 2000a,b) or 'imagined communities' (Anderson, 1983). Underlying each of these concepts is the notion of a socially constructed, rather than territorially bounded, nation. Much like the territorially bounded version, however, imagined or socially constructed communities also rely on a level of 'shared heritage, values and culture' (see Willis et al., 2004, 2 for more discussion). Reid offers a more refined and less nation-based conceptualization of a socially constructed community - what he labels 'ethnie nationalism' (Reid, 2010, 6). Reid writes that '[f]or Asia in particu-

\footnotetext{
${ }^{1}$ Repatriation incentives offered by the Kazakhstan government vary through time and the program was temporarily suspended from 2012 to 2014. See Barcus and Werner (2010) for an overview of the changing periods of incentivized repatriation policies.
} 
lar, ethnie has the advantage of escaping the positive emotive associations of 'nation', the currently negative (but once positive) ones of 'race', and the necessarily sub-national ones of ethnic group' (Reid, 2010, 7). Ethnie nationalism can be described through six characteristics (see Table 1).

The basic premise that communities need not be territorially bounded seems to have fundamentally changed the landscape of scholarly inquiry into the concept of nationalism. Writing in 1983, Anderson could not have imagined the advent, and indeed pervasiveness, of the internet and mobile phones, as inexpensive and effective devices for social organizing and community defining. The break-up of the USSR and push by political elites in the FSU to gather dispersed diasporas back to their (imagined) 'homelands' provides evidence of the power of 'imagined' communities. However, as Tsuda (2009) explains, many ethnic return migrants around the world have failed to fully identify with their newly bounded territories and kin. For these individuals and families in post-Soviet spaces who chose not to repatriate fully and instead remain in their origin (i.e. Kazakhs that remain in Mongolia) the concept of ethnie nationalism provides a useful framework for understanding the decision not to migrate 'back' to the 'homeland' but rather to remain 'immobile'.

\section{Place identity, cultural identity and the narrative of identity}

'Place is the location in which people struggle to achieve goals and understand their existence. Through struggle, meaning is built into inanimate objects that give place symbolic significance. This meaning can become a part of social identity - a place-based identity for groups within society'.

[(Harner, 2001, 661)]

Place identity is an intimate connection between an individual and the physical environment, both natural and built, that constitutes a 'place'. It is a sub-structure of self-identity that includes cognitions about an individuals' physical world, attitudes, values, feelings, memories and meanings, inclusive of their past interactions with a particular physical environment (Proshansky et al., 1983). It includes associations with people set within these physical settings, varies by the socio-demographic characteristics of individuals, and is mediated by life stage (Proshansky et al., $1983,60)$. As a social construction, it is developed through interaction with a place and is comprised of the interactional past (memories of interactions associated with the site) and interactional potential (future experiences viewed to potentially occur at the site) (Milligan, 1998). 'Identity has both personal and collective dimensions, and is tied up with gender, class, ethnicity, age and styles of living,' moreover it '. . is bound up with geography and place: as homeland (nation) and home place (community) and in relational terms as one's 'place' in the world (Tuan, 1996)' (McHugh, 2000, 85). As a 'materialized discourse', landscapes can also contain representative symbolism that asserts or reinforces power relations between social groups (Harner, 2001, 662). Such symbolism can reinforce within-group identity by maintaining accepted representations of social order or processes.

Place-based attachments have been examined in studies of the Global North (De Jong, 2000), yet they have been neglected in studies of migrants whose destination is a developing or transitioning country. Individual decisions to migrate, or remain in place are always made within a specific social, cultural, and institutional context. In developing and transition countries, however, these decisions tend to be more dependent upon local social conventions, individual social networks, gender and family expectations, and religious practices (Massey et al., 1993; De Jong, 2000; Guilmoto and Sandron, 2001; Pessar and Mahler, 2003). Further, as transnational networks continue to expand the idea of home and homeland and the ways in which migrants or potential migrants imagine the home to which they are migrating and that which they are leaving also become increasingly complex, challenging long-held notions of identity and belonging.

Culture and place identity are tightly linked (Relph, 1976; Tuan, 1980). 'Place identity is a cultural value shared by a community, a collective understanding about social identity intertwined with place meaning' (Harner, 2001, 660). Place identity, thus, is one part of cultural identity. As with all aspects of cultural identity, place identity is mediated through an individual's interaction with other members of their family and community as well as with external sources of information and perceptions. It may also be held in common by families and the desire to return to a particular place, not just a particular home dwelling, may transcend generations (White, 1983, 1989; White and Brunn, 1994; Barcus and Brunn, 2010). An individuals' perception of place identity is conditioned by their own social position and experiences, inclusive of cultural norms. Thus each individual is affected by the normative cultural values of a social group but may also express agency in choosing to accept or reject both the values and the practices associated with those values in that particular social group.

One example of place identity is the concept of a homeland, through which place identity may be created or further reinforced. Contemporary homeland narratives symbolically link a particular 'imagined community of people' with a specific territory, 'that is described as being the place from which the group emerged and the place to which that group belongs' (Jones, 2011, 376). The creation of a 'homeland' is imbued with power as it is the vision of one group to delineate who belongs and who does not belong to the ascribed territory. These discourses are often developed and perpetuated by political and cultural elite (Kuşçu Bonnenfant, 2012, 32). In Kazakhstan, for example, the call by newspapers for co-ethnics to return to Kazakhstan emphasized the importance of 'blood brothers' who were forced to leave the homeland historically and the desire to see these 'victims' return home (Kuşçu Bonnenfant, 2012). Noting that the political process of defining a homeland resonates with Hobsbawm and Ranger's (1983) concept of 'invented traditions,' Jones argues that '. . .localized practices are selectively reanimated as representative of the entire group of people that live in a large territory' $(2011,376)$. The homeland narrative, then, constructed by political and economic elites, calls upon not just the geographically defined territory of a 'homeland' but also commonly held cultural practices, the acceptance of which, unites various components of the diasporic communities.

A third perspective on the intersection of place, culture and identity is the role of narratives in creating, reinforcing and perpetuating concepts of belonging. Somers argues that '... it is through narrativity that we come to know, understand, and make sense of the social world, and it is through narratives and narrativity that we constitute our social identities' (Somers, 1994, 606). For example Kaiser and Nikiforova (2007) explore the cultural politics of memory including the re-narration and re-enactment of the past through '... the reconfiguration of common landscapes...' (Kaiser and Nikiforova, 2007, 935)... '...official and unofficial uses of sites of memory; and the local populations narrative emplotment and performance of identity in and through these sites of memory in everyday life' (Kaiser and Nikiforova, 2007, 935). Narrativity thus is a means by which individuals come to create and understand their own identities.

Approaching the topic from a slightly different angle, Anderson (1983) also acknowledges the role of narratives of culture as well as cultural products in influencing notions of national identity. He writes that ' $\mathrm{t}$ ] he cultural products of nationalism - poetry, prose fiction, music, plastic arts - show this love [of nation] very clearly in thousands of different forms and styles' (Anderson, 1983, 141). The construction of social and cultural identity then 
Table 1

Characteristics of Ethnie Nationalism (Reid, 2010, 7).
1. A collective name,
2. A common myth of descent,
3. Some shared history or set of traditions,
4. A distinctive shared culture, usually including language or religion,
5. An association with a territory, either present or past (though one of sacred sites and centres rather than boundaries),
6. A sense of solidarity.

is at least in part based on the 'narratives' of the past, present and future as exemplified by landscapes, artistic and literary works, and memory. These narratives, however, do not tell a uniform or necessarily consistent story. As Hereniko (1994) points out, ' . . cultural identity is process, not product' (407) and one that finds different interpretations at the level of the individual, the nation, and possibly, the region (418-427).

\section{Migration and the decision to return to ethno-national homelands}

Many Mongolian Kazakhs first embarked on their 'return' to the 'Kazakh homeland' of Kazakhstan in the early 1990s. Although few had ever visited Kazakhstan, the narratives created by Kazakh political elites coupled with generous repatriation incentives facilitated the movement of nearly 50\% of the Mongolian Kazakh population (Diener, 2009). By 2000, up to one-third of those early migrants had returned to Mongolia, despite comparatively unfavorable economic conditions in Mongolia. ${ }^{2}$ Many more have chosen not to migrate to Kazakhstan. Thus the narrative of 'homeland' offered by the Kazakhstan government failed to fulfill the expectations and imaginings of Mongolian Kazakhs. Twenty-years posttransition, however, many Mongolian Kazakhs have re-imagined their own cultural and geographic narrative drawing on place-based and cultural identities only partially shared by non-Mongolian Kazakhs. We employ the concept of 'narrative identity' and 'ethnie nationalism' to explore the ways in which Mongolian-Kazakhs are re-creating and re-establishing place identities in Mongolia and ultimately re-imagining Mongolian-Kazakh community and identity. These recreated place identities have emerged among MongolianKazakhs who chose to remain immobile or return migrated from the 'homeland' of Kazakhstan.

\section{Ethnic Kazakhs and the repatriation to Kazakhstan from Mongolia}

Kazakh families traditionally were livestock herders, raising sheep, yaks, camels, goats and horses and conformed to gender roles in which men cared for the livestock and women maintained the household, including textile production, child tending and food preparation (Bacon, 1996; Werner, 1997). Agricultural collectivization reoriented livestock production from subsistence to state-controlled, during the communist period (Finke, 2003). During the same period, the state expanded access to state sponsored health care, education, and social welfare. Today, a significant segment of the population continues this herding heritage, as semi-nomadic pastoralists move seasonally between a fairly regular set of pastures and earn cash from livestock products (such as cashmere). These herders possess an intimate knowledge of the landscape and resources available at each location, and they migrate in regular patterns from one pasture to another. While there are customary agreements, these are continuously renegotiated. Despite the encroachments of a modern state, this region of western Mongolia remained relatively isolated from outside cultural influences. One outcome of this

\footnotetext{
${ }^{2}$ Few reliable sources exist on return migration of Kazakhs to western Mongolia. Two other scholars working in the region provide estimates that range from 10,000 to 20,000 return migrants (Diener, 2009; Finke, 1999).
}

isolation was the preservation of many cultural practices that transformed to a greater extent in Kazakhstan and elsewhere. Indeed, Mongolian Kazakhs are well-known in Kazakhstan for their knowledge and preservation of Kazakh language and cultural 'traditions'.

Three contemporary or near historic national-scale structural factors are particularly salient in understanding Kazakh migration between Mongolia and Kazakhstan. First are the economic and political transitions of the 1990s (see Barcus and Werner, 2010; Werner and Barcus, 2009). The second and third factors are tightly intertwined: the pervasive meta-narratives of homeland and its coupling with strategic immigration policies and incentives from the Kazakhstan government. Although Kazakhstan gained independence in 1991, it was during the first Qurultay (or Congress) of the newly formed World Kazakh Organization in 1992 that President Nazarbeyev emphasized the importance of Kazakhstan as the homeland of all Kazakhs. The importance placed on the repatriation of ethnic Kazakhs to the 'homeland' helped establish a framework of immigration and integration policies to aid ethnic Kazakh migrants 'return' to Kazakhstan. In turn, these policies have created incentives for potential migrants living outside of Kazakhstan (Kuşçu Bonnenfant, 2012, 31).

Compared to other Kazakh diasporic populations, the Kazakhs from Mongolia have one of the highest rates of repatriation. Early estimates suggest that approximately $50,000-60,000$ of the 120,506 Kazakhs living in Mongolia in 1989 (NSOM, 2003, 367) chose to migrate to Kazakhstan between 1992 and 1999. ${ }^{3}$ By 2000 , however, estimates suggest that $10,000-20,000$ of the original migrants returned to Mongolia (Diener, 2009). Despite challenges faced by ethnic migrants to Kazakhstan, such as housing, unemployment, limited Russian language skills, and discrimination from local residents in Kazakhstan, about two-thirds of the repatriated Kazakhs remained in Kazakhstan (Diener, 2009; Werner and Barcus, 2009; Kuşçu Bonnenfant, 2012; Barcus and Werner, 2010). Those who did not stay cited largely non-economic reasons for returning to Mongolia. Similar challenges have been experienced by Kazakh oralman from other countries; however, there is no evidence to suggest that oralman from other countries are returning to their home country (Cerny, 2010; UNDP, 2006).

During the most recent period in which our work takes place, it is clear that the once dominant economic rationale for migrating has become more nuanced. Economic motivations remain key, but other important factors are embedded in the decision process. Kazakh culture emphasizes locality and place, especially birthplace and ancestral burial grounds, creating strong cultural narratives about places and their role in forming Kazakh identity.

Our analysis is informed by data we collected during three summer field seasons in Bayan-Ulgii, Mongolia (see Map 1). We chose a case study approach utilizing a range of methods in order to tease out nuances in migration expectations and experiences. In 2006 we conducted semi-structured interviews with urban and rural Kazakhs in western Mongolia that focused generally on migration

\footnotetext{
${ }^{3}$ For a portion of Kazakh residents of Bayan-Ulgii, UlaanBaatar was also a potential migration destination. Census records for this period don't allow a specific accounting of origin and destination flows but the Kazakh population in UlaanBaatar, the most commonly mentioned destination other than Kazakhstan, increased from 5634 to 6439 between 1979 and 2000 (NSOM, 2003, 377).
} 
experiences and changing economic conditions. By the time we started this research, there were well-developed networks linking residents of Bayan-Ulgii to migrants living in a range of rural and urban areas in Kazakhstan. All of the Kazakhs we interviewed know of friends or family living in Kazakhstan, although only $28.4 \%$ belonged to a household in which no other household members had migrated.

In 2008 we returned to Bayan-Ulgii and completed 184 structured interviews. Our survey instrument comprised more than two-hundred questions. We sought information about several key areas including household composition and economic status, as well as migration preferences, expectations, and experiences (for those who had previously migrated). The survey utilized a nested quota sample that included an equal number of participants along several key variables: geography (urban vs. rural), migration status (migrant-sending vs. non-migrant household), age (20-29, 30-44, and 45 and older), and sex/gender (male vs. female). Quota samples approximate probability sample results and generally reflect population parameters of interest (Bernard, 1996, 188; Schensul et al., 1999, 246). In this study, 'urban' refers to individuals who live in the central town of Ulgii, which had a population of approximately 28,060 individuals in 2000 (NSOM, 2001, 32). 'Rural' residents include semi-nomadic herders who live in pasture communities and rural residents who occupy small towns that serve as local administrative centers. In addition to location, we selected respondents to reflect a mix of economic status in order to broaden our sample. We identified potential respondents through snowball sampling techniques, relying on key informants in each of the communities and pasture areas we visited.

We determined the migration status of a household through a series of questions eliciting information about whom, if anyone, within the household migrated to Kazakhstan between 1991 and 2008. We acknowledge that household composition is constantly changing, with the birth and death of household members, as well as the movement of individuals from one household to another. For the purpose of our survey, we designated households in which no family member had migrated to Kazakhstan (or another foreign country) as 'non-migrant households.' If a household indicated that at least one former household member currently lived in Kazakhstan (or elsewhere abroad) or at least one current household member previously lived in Kazakhstan (or elsewhere abroad) for at least six months before returning to Mongolia, we labeled that household as a 'migrant-sending' household. Few of the 'migrantsending' households in our sample were return migrants. This initially surprised us given the estimates of return migrants. However, the vagary of legal status for some return migrants, coupled with the existence of circular migration, made it somewhat difficult to locate return migrants who were willing to discuss their experiences. In this paper, we do not address the similarities and differences between migrant-sending households and nonmigrant-sending households, in part because there are no significant differences between these groups in regards to the issues addressed in this paper.

In addition to the questionnaires, we conducted 'life history' interviews with approximately one out of seven individuals in the survey. These interviews lasted between one and three hours. Interviews included a variety of topics, such as education, marriage and family, health, work, and religious practice. These interviews contextualized our understanding of the survey results and we rely heavily on them to understand the nuances in migration decisions that are often only alluded to in the surveys. Our knowledge of Bayan-Ulgii province and our understanding of migration processes are also enriched by participant observation in the community, informal conversations with a wide range of individuals, and a review of policy documents, statistical records, and other source material.
We utilize two primary software packages to analyze our data. SPSS 17.0 (SPSS, 2008) allows for statistical analysis, such as crosstabs and basic descriptive statistics. All interviews were digitally recorded, transcribed, and translated into English. Original interviews were conducted in Kazakh, the primary language of Mongolian Kazakhs. We also utilize ArcGIS 10.1 (ESRI, 2011) to assess the spatial distribution of interviews and create maps.

\section{Re-territorializing identity through language, religion and kinship ties}

\section{Religiosity and religious practices}

Muslim religious identity is instrumental to Kazakh ethnic identity. During the communist period, Kazakhs could not openly practice Islam in either Mongolia or the Kazakh Republic of the Soviet Union. Many of our older informants spoke of how their parents and grandparents secretly maintained their religious practices during the communist years.

Government restrictions on religion help explain why many Kazakhstani and Mongolian Kazakhs today do not participate in regular prayer or fasting rituals (Finke, 1999). Nevertheless, for Mongolian Kazakhs, ethnic and religious identities are deeply intertwined (Privratsky, 2001; Asad, 2009; Brede, 2010). As one respondent noted 'If a person is Kazakh, that person must be Muslim' (U-LH-2, 2008). However, there is a slight paradox: while most Mongolian Kazakhs consider themselves to be Muslim, the majority do not adhere to the five 'pillars of Islam' (Portisch, 2006, 2; Brede, 2010).

After years of religious repression under communism, the building of new mosques and availability of scholarships to study Islam abroad contribute to the revival of Islam amongst Kazakhs in Bayan-Ulgii. Since the early 1990s, increased access to international television, the internet and, importantly, friends and relatives living abroad, local understandings of Islam are changing among Mongolian Kazakhs. Changing conceptualizations of Islam, including locally derived interpretations of piety and practice, and global discourses about proper Islamic beliefs and practices, produce widely variable interpretations of what it means to be Muslim. However, there does seem to be consensus in the belief that all Kazakhs are Muslim. In Central Asia, more broadly, '[Islam] is perceived not merely as an abstract component of collective and individual identity but as a key element, informing one's habits and customs' (Ro'i and Wainer, 2009, 303). In the mid-1990s, Peter Finke noted a growing interest in religion among Mongolian Kazakhs in Bayan-Ulgii (Finke, 1999). A decade later, Brede writes that 'With respect to religious practice itself, private, public, mosque-based, and shrine-based activities [are] the primary practical modes by which informants interpreted the idea of piety...' and '...practices like namaz have grown rapidly in popularity in most areas, but for most individuals the most important religious practice in mosques is almsgiving' $(2010,147)$.

Religion and certain religious beliefs or practices, such as shrine visitation, create and reinforce place identity. While there are many dimensions to religious practice, two practices that link place identity and migration for Mongolian Kazakhs include visitation to local shrines (mazar), especially ancestral burial sites (zirat), and the belief that religion can be practiced more easily in a particular place. Practices such as namaz are not specific to a particular mosque, but rather more ritualistic in practice. In contrast, shrine-based activities, particularly the visitation of ancestor burial sites are site-specific, and one shrine cannot be substituted for another. A more orthodox interpretation of Islam forbids the creation of large tombs and the veneration of any living or dead person other than God (Dawut, 2009, 65). Yet, throughout Central Asia, 


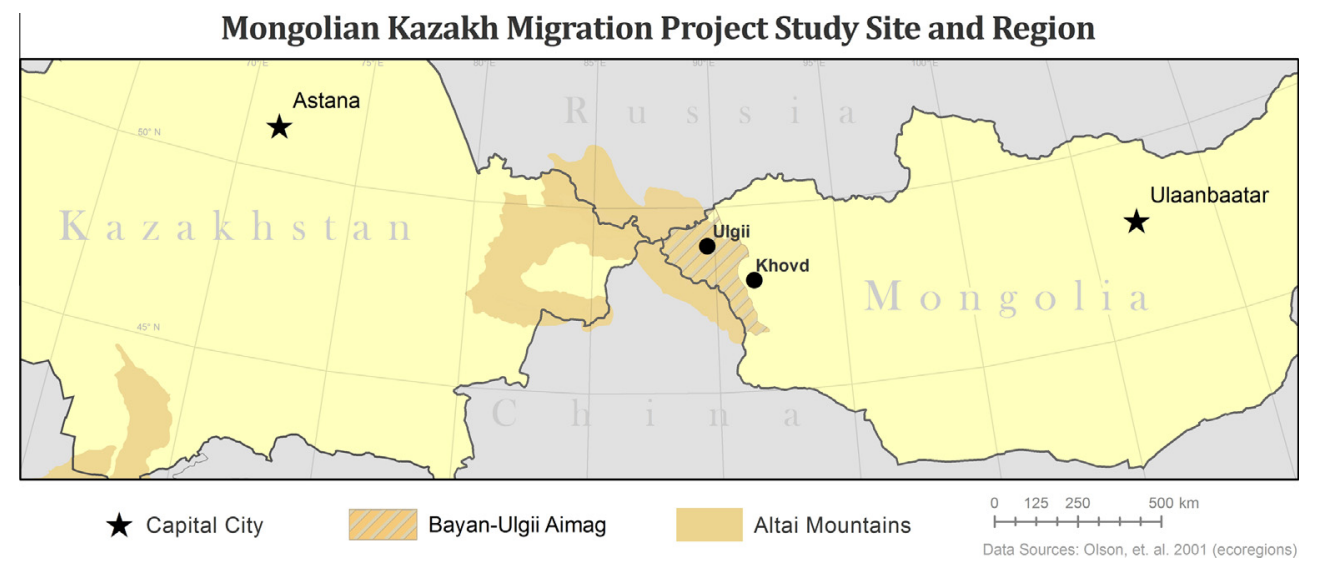

Map 1.

scholars have frequently observed the importance of shrine pilgrimage in local religious practices due to influences of pre-Islamic practices and Sufi elements of Islam (Privratsky, 2001; Louw, 2006; Abramson and Karimov, 2007). Believing that saints and ancestors are closer to God, Central Asians travel to the grave sites of saints and other historically important figures, especially on occasions when they have the need to ask for a blessing. Due to a relatively short period of occupation in western Mongolia, the landscape does not contain shrines on the same magnitude as those found in other regions (such as the Akhmed Yasavi shrine complex in the Kazakhstani city of Turkestan). Mongolian Kazakhs, however, perform similar rituals, albeit on a much smaller scale, at the graves of their ancestors. For example, when they visit an ancestral grave, they typically recite a particular prayer (ayat). The Kazakhs we interviewed believe that this prayer helps their ancestors reach paradise, and some also believe that these prayers can help them receive blessings in return.

The importance of ancestor burial sites, and the ritualistic visitation to these sites at important life stages and at key intervals (such as the anniversary of a death), creates a tangible and spiritual connection to a particular geographic place. The veneration of a burial site permeates the dual religious-ethnic identity of Mongolian Kazakhs. Burial ceremonies extend through time and are connected to place. It is Kazakh tradition to hold a series of memorial events where family members gather to acknowledge seven days, forty days, and one year after an individual's death (Finke, 1999, 137). Burial and the bodies of national 'heroes' can figure into the narratives of nation-building. As Verdery states '[n]ationalism is ... a kind of ancestor worship, a system of patrilineal kinship in which national heroes occupy the place of clan elders in defining a nation as a noble lineage' $(1999,41)$. Interestingly it seems that through the act of embracing ancestor burial sites in Mongolia through visitation rituals, Mongolian Kazakhs are embracing a particular narrative of 'Kazakh identity' not only outside of the territorial boundaries of Kazakhstan, but in some ways privileging family burial sites and the connection to these places over burial in Kazakhstan. As one informant noted: 'It is important to bury someone in their birthplace. If people die in Kazakhstan, if they have the money, they should be buried with their family in Mongolia' (U_2009_08). In Mongolia, there are few shrines of Kazakh national heroes, such as local saints found throughout Central Asia, but visiting shrines of ancestors remains important for linking multiple generations together and reinforcing ties to place, even if the place is outside of the territory of the national 'homeland'.

In our survey and interviews we ask a series of questions about migration and the role of religious practices in shaping migration decisions (See Table 2). The responses are indicative of the conflicted ideals about religion and religious practices. Overall, only
$14.1 \%$ of respondents stated that they recite namaz daily. Adopting local meanings associated with this practice, we use this question as a proxy for gauging religiosity or devotion to Islamic religious practices. Of those who recite namaz daily, there was an interesting divide by both gender and age. On average, men take part in daily prayers more frequently than women, and younger (18-29) and older (over 45) individuals of both sexes are more likely to recite namaz daily than their middle-aged counterparts. Of the 70 respondents in the middle age group (30-45), only three recited namaz daily. Our findings are similar to that of other scholars who have studied religiosity in Central Asia. Ro'I and Wainer explain that the Five Pillars are not exclusive markers of Muslimness in Central Asia, but rather that, for some, these rituals are considered the domain of the elderly, impractical for working people, and therefore rituals that are postponed until later in life (2009, 306). In a separate study, we argue that the younger age cohort is also more religiously oriented, and that this is best explained as an outcome of transnational flows of religious information (Barcus and Werner, 2014).

In one question we asked respondents to compare their expectations about life in Kazakhstan with their experiences of life in Mongolia. We provided 28 prompts describing expectations for income, marriage, cultural traditions, crime, life style, occupation, education, and religion. Interestingly, for the three questions about cultural traditions and religion, the majority of respondents, irrespective of age and sex, expected that each of these would be easier to maintain in Kazakhstan. This isn't surprising given that the Mongolians, the dominant ethnic group in Mongolia, are not Muslim, while in Kazakhstan the dominant ethnic group is Muslim. In contrast, when asked in a later question about why they choose to stay in Mongolia, a substantial percentage answered that the presence of their ancestors' graves was an important reason to stay. This contradiction underscores the sentiment expressed in many of the interviews - that there are particular elements of place that are highly valued by individuals; so much that individuals might choose to remain in place or return to Mongolia in order to maintain connections to these places.

In sum, while Mongolian-Kazakhs consider their ethnicity to be deeply intertwined with their religious identity, religiosity and religious practice vary across social status, gender, and life stage. Place-based religious beliefs, such as ancestor burial sites, are actively considered in the migration decision process. The degree to which it is a viable reason for remaining in place seems more important to older respondents than to youth, possibly also reflecting how the intimacy of place connections may grow with increased age (and the corresponding likelihood that parents, siblings, and even children might be buried in Mongolia). 
Territorial-based kinship identities

'Traditional' Kazakh social structure corresponds to the anthropological concept of a 'patrilineal segmentary lineage system,' such that the Kazakh ethnic group is subdivided into three geneaologically defined smaller units, which are further subdivided into smaller units. In Western scholarship, the larger units are often referred to as the three Kazakh 'hordes' (zhuz in Kazakh) while the smaller units are alternatively referred to as 'clans,' 'tribes,' or 'tribal lineages' (ru in Kazakh) (Esenova, 2002; Schatz, 2004). In practice, the existence of this segmented and geneaologically defined lineage system means that the typical Kazakh identifies with multiple sub-ethnic identities, in addition to the ethnic-based category of being Kazakh. For example, a Mongolian Kazakh might simultaneously identify as a Kazakh, as a member of the Middle Horde, as a member of the Kerei tribe (maximal lineage group), and as a member of the Zhantekei tribe (minimal lineage group). One important feature is that they are ascribed identities inherited from one's father, which means that one's primary kinship identities are shared with one's father, one's siblings, and one's father's relatives (but not with one's mother or her relatives). Kazakhs tend to be exogamous at the minimal lineage level.

Another important feature of this system is that all levels of these kinship-based identities are loosely associated with specific territories or landscapes, or more accurately, one could argue that these kinship-based identities have shifting connections to particular landscapes that change over time. For Kazakhs in Mongolia, these affiliations remain strong in the contemporary period. There are three 'tribes' represented in Mongolia: the Kerei, Naiman, and Uak lineages. Although there are Naiman and Uak in Mongolia, the Kerei are by far the dominant group. For a period of time in the 20th century, lineage identities were visibly linked to geographic areas, and served as the names for local administrative units (Finke, 1999, 130). Although this is no longer the case, lineages still tend to be concentrated in particular districts (soms) within Ulgii and Hovd Aimags (Finke, 1999, 131). Despite attempts to restructure the pastoral economy and weaken kin-based loyalties during the socialist period, Mongolian Kazakhs retained strong kinship bonds and lineage solidarity (Finke, 1999, 129). These bonds are notable today as many respondents refer to these identities on a daily basis when they meet other Kazakhs or discuss potential marriages.

The social importance of these kinship identities and the corresponding geographic concentrations create strong linkages between the land of a particular place and its incorporation into the cultural identity of individuals and families. Given that minimal lineages are geographically concentrated, it follows that maintaining a presence in the territory becomes an increasingly important aspect of these identities. It is particularly important because it reinforces strong kinship bonds and lineage adherence. Thus place identity is fostered through the generational ties to a territory, and reinforced through the importance of birth and burial sites.

Our surveys further confirm that siblings and adult children, especially brothers and sons, often maintain these place-based kin networks by living in close proximity to one another. Adult sisters and daughters are more likely to live outside of the immediate community where they were raised due to the cultural expectation that they marry outside of the minimal lineage group. For rural Kazakhs still engaged in a herding livelihood, family groups often settle together in a summer pasture settlement (aul). An aul is comprised of several related households, usually three or four, who maintain separate household economies on some levels, but share labor and resources on other levels. For example, in our rural homestays, it was common for households within the aul to herd all of the collective animals together, and share the responsibilities of milking, herding, and shearing. For some activities, such as shearing, we also observed that multiple auls would work together. Although migration has separated kin groups, most of our respondents (especially men) had at least one, if not several, close relatives living within five miles of their home. Our life history interviews supported these findings. Since the majority of rural interviews were conducted in remote pastures, this density of kin relations is notable and underscores the importance of these networks in maintaining social and place ties. It also suggests the striking changes that family members would face if a household chose to migrate to Kazakhstan where kinship ties are weaker. These place ties are maintained even at great distances as daily text messages keep families connected to kin in Kazakhstan regardless of the remoteness of summer pasture life (field notes 2008, 2009). ${ }^{4}$

Today these clan lineages are less geographically concentrated as individuals and families continue to move away from nomadic livelihoods to centers of commerce such as Ulgii, Ulaanbaatar, and destinations further afield, such as Kazakhstan and Turkey. But the importance of place is infused into the cultural norms of Mongolian Kazakhs. The comments of one respondent in particular highlights the importance of place.

'Four of my siblings migrated [to Kazakhstan]: three brothers and one sister. Several of my relatives followed them. Those of us who stayed are all in this place, but there are few of us.... My parents are buried here, and we have remained here. If things get worse in the future, we will need to migrate. But I always ask how can we leave our own country, our homeland where we were born and raised. ... Sometimes I do think about it [migration to Kazakhstan], and my children know this. I usually don't want to migrate, but sometimes I do want to go. If you go there, life is essentially the same. But, it will never be as good as the place where you are born and raised. The water, the land, and the climate are all different, and just won't be the same as here'(U-LH-10).

The intersections of migration, place and kin and the conflicted feelings of this respondent toward permanent migration to Kazakhstan underscore the depth to which place connections are infused into and inform perceptions of and attachments to place amongst this population.

The choice to remain in or return to Mongolia reflects a desire to remain connected to land or territory associated with ones' birthplace or the burial sites of ancestors. Such deeply held place identities are rooted in particular territories which are locations of these culturally significant events. While grounded in these cultural practices and beliefs, the narratives surrounding these specific places or territories in Mongolia, provide a compelling rationale for choosing to remain immobile.

\section{Linguistic versatility}

Linguistic versatility is often the product of exposure to and dependence upon a particular set of languages. For Mongolian Kazakhs who have retained linguistic knowledge of their native tongue, Kazakh, linguistic versatility is both a product of location and of age. As a semi-autonomous province, Kazakhs have had the freedom to speak Kazakh, which is the dominant language in Bayan-Ulgii Aimag although Mongolian is the language of interethnic communication (Finke, 1999, 138; Werner and Barcus, 2009; Barcus and Werner, 2010). The result is that while the majority of Mongolian Kazakhs are fluent in Kazakh, many are also

\footnotetext{
${ }^{4}$ Mobile phone access in Bayan Ulgii is often dependent upon topography (mountain tops have better reception than narrow valleys) and proximity to settlements, such as soum and aimag centers.
} 
Table 2

Selected survey responses.

\begin{tabular}{|c|c|c|c|}
\hline Question context & Responses & & \\
\hline $\begin{array}{l}\text { Compare statements about living in Kazakhstan as compared to living } \\
\text { in Mongolia. Response options are Very High Expectation (VH), } \\
\text { High (H), Neutral Expectations (N), Low (L), or Very Low } \\
\text { Expectation (VL) }\end{array}$ & $\begin{array}{l}\text { Response } 1 \text { : } \\
74.4 \% \text { expect that they will } \\
\text { feel closer to Kazakh culture } \\
\text { in Kazakhstan }\end{array}$ & $\begin{array}{l}\text { Response } 2 \text { : } \\
76.1 \% \text { expect that it will } \\
\text { be easier to be a Muslim } \\
\text { in Kazakhstan }\end{array}$ & $\begin{array}{l}\text { Response } 3 \text { : } \\
72.8 \% \text { expect that it will be easier } \\
\text { to teach their children about } \\
\text { Islam in Kazakhstan }\end{array}$ \\
\hline $\begin{array}{l}\text { Reasons for staying in Mongolia. Rate the importance of each reason } \\
\text { as Very Important, Somewhat Important, Don't Know, } \\
\text { Unimportant, or Very Unimportant }\end{array}$ & \multicolumn{3}{|c|}{$71.8 \%$ stay because ancestors are buried in Mongolia } \\
\hline Do you recite namaz daily? (Yes or No) & \multirow{2}{*}{\multicolumn{3}{|c|}{$\begin{array}{l}14.1 \% \text { (of } 184 \text { ) practice Namaz daily } \\
170 \text { or } 92.4 \% \text { listed places in Mongolia, mostly in Bayan Ulgii aimag (other responses = } \\
\text { Kazakhstan 12, China 1, Don't know 1) }\end{array}$}} \\
\hline Where are your close relatives buried? & & & \\
\hline
\end{tabular}

proficient in Mongolian, depending on their educational background and life experiences. During the socialist period, parents living in Ulgii had the option of sending their children to a 'Mongolian'-language school where Mongolian was the primary language of instruction, or a 'Kazakh'-language school. At Kazakh-language schools, Mongolian would be taught as a second language. As a general rule, fluency in Mongolian language is more common among the economic and social elite, as Mongolian language was important for social mobility. Similarly, those old enough to be of age during the socialist period might speak Russian, particularly if their status within the Communist Party was high enough that they may have been educated in Russia.

For younger generations, Kazakh continues to be the first language, but English has increasingly become a common second (or third) language. Today, school-age children in Ulgii have the option of attending schools in which the language of instruction might be Kazakh, Mongolian, Turkish or English (Finke, 1999, 118; Diener, 2009). (English and Turkish are the primary languages of instruction at the local 'Turkish' school, a highly regarded private school operated by expat Turks affiliated with the Fethullah Gulen movement). In rural areas populated by Kazakhs in both Bayan-Ulgii and Khovd provinces, Kazakh is the only language of instruction, although English is increasingly available as a second language as a greater number of young teachers enter the profession and begin their careers in rural communities.

Despite the remoteness of this province, linguistic versatility is a vital skill for economic survival and one that greatly facilitates international trade or permanent migration to Kazakhstan or further abroad. Understanding Chinese is also valuable because cross-border trade with China offers economic opportunities, although few Kazakhs we encountered are proficient in Chinese. Russian is important for this reason as well, as Bayan-Ulgii serves as a trading hub, such that a large volume of goods pass from China through Bayan-Ulgii to Russia. Finally, Arabic language skills are necessary for Kazakhs who are interested in learning more about Islam. Most of the new generation of local mullahs studied Islam abroad (in Turkey, Egypt, Saudi Arabia, or Kazakhstan), and their religious education includes the study of Arabic.

For Mongolian Kazakhs who want to migrate to Kazakhstan, Russian and English offer the greatest utility. For example, for migrants to Kazakhstan, Russian language proficiency is necessary for daily life and broader integration into Kazakhstani society. This need for linguistic versatility was a key issue for migrants in the early 1990s, as Peter Finke reveals:

'While the reasons for emigration were mainly economic, those for the re-migration are more manifold. In the northern parts of Kazakhstan, where most of the arrivals settled, the population is made up mostly of Russians and a few Kazaks and Germans. It seems that the Kazakhstan government settled the migrants in this area to fill the gap caused by the massive emigration of Germans in recent years, and to make this part of the country somewhat more 'Kazak'. Under these circumstances it is easy to imagine how the newcomers were welcomed, even more so considering the fact that the economic situation in the countryside of Kazakhstan is probably even worse than that of Mongolia. Moreover, most of the native Kazakhs in northern Kazakstan speak no Kazak, while migrants from Mongolia do not speak Russian very well'.

[(Finke, 1999, 116)]

A decade later, our interviews yield similar findings; proficiency in Russian facilitates migration and assimilation in Kazakhstan. Those who returned to Mongolia often spoke of their struggle with the Russian language and how this inhibited their ability to work in Kazakhstan. One female return migrant states 'It is important to know Russian. When my family lived in Kazakhstan, my children went to a Russian language school. It was hard for them and they didn't feel comfortable. Because of this they only went two out of five days a week... Professional women need to know Russian in order to get a job' (UH_2009_03). Paradoxically, our questionnaires reveal that while respondents have relatively mixed opinions about where it is easier to educate children in the Kazakh language, most respondents find that using Kazakh language in daily life is easier in Mongolia (See Table 3). This is not surprising when one considers the linguistic landscape of the two countries. In western Mongolia, Kazakh is universally spoken by the majority of residents of Bayan-Ulgii. In comparison, although Kazakhstani Kazakhs have become increasingly proficient in the Kazakh language since the early 1990s, some Kazakhs still consider Russian to be their primary language of communication, and Kazakh is rarely spoken by non-Kazakhs (who make up about a third of the country's population)(Fierman, 2005; Davé, 2007). While linguistic challenges are common for migrants moving to a new country, what is unique in this case is that these are ethnic return migrants who are returning to a 'homeland' and speaking the native language, yet they still face linguistic challenges.

Linguistic versatility facilitates successful long-term migration, while lack of linguistic versatility frequently results in return migration to Mongolia. Despite political narratives that portray all Kazakhs as members of the 'homeland', those who lack sufficient language skills in Russian continue to identify as Mongolian Kazakh, and interact primarily with other Mongolian Kazakhs while living in Kazakhstan. As a result they associate that identity with Mongolia and their particular community in western Mongolia. In this way, individual identities are conflated, through language, with a specific place in which that language is widely understood.

\section{Conclusion: Toward a refined understanding of identity, territoriality and ethnicity}

Proshansky et al. (1983) described place identity as a sub-structure of self-identity and Harner postulated that it '.. is part of social identity - a place-based identity for groups within society' (Harner, 2001, 661). The incorporation of place as self and as a 
Table 3

Teaching and using Kazakh Language.

In which place is it easier to:

\begin{tabular}{|c|c|c|c|}
\hline & Bayan-Ulgii & Kazakhstan & Equal/same \\
\hline Teach children about Kazakh language & $39.1 \%(72)$ & $27.2 \%(50)$ & $33.7 \%(62)$ \\
\hline Use Kazakh language in daily living & $60.3 \%(111)$ & $20.1 \%(37)$ & $19.6 \%(36)$ \\
\hline
\end{tabular}

connection between self and society creates strong linkages between particular geographic spaces and individuals' conception of self and, ultimately well-being. We have argued in this article that Mongolian Kazakhs actively employ narratives of their cultural history to re-create and re-establish place identities in Mongolia and ultimately re-imagine Mongolian-Kazakh community and identity. These recreated place identities have emerged among Mongolian-Kazakhs who chose to remain immobile or return migrated from the 'homeland' of Kazakhstan. Specifically cultural elements such as linguistic ability, kinship ties, and religiosity, can inhibit out-migration and facilitate return migration for some Mongolian Kazakhs in western Mongolia, despite economic advantages to permanent migration to Kazakhstan.

While the creation of new nation states and national identities has spawned widespread migration across the former Soviet Union, such 'nationalistic' identities fail to fully incorporate ethnic return migrants. One outcome is the exclusion and discrimination against repatriates in the 'homeland'. Another outcome, we argue, is the (re)assertion of place based territorial identities in the country of origin. In this essay we employ the concept of 'narrative identity' and 'ethnie nationalism' to explore the ways in which Mongolian-Kazakhs are re-creating and re-establishing place identities in Mongolia and ultimately re-imagining Mongolian-Kazakh community and identity. These recreated place identities have emerged among Mongolian-Kazakhs who chose to remain immobile or return migrated from the 'homeland' of Kazakhstan.

Mongolian Kazakhs fit Reids' concept of 'ethnie nationalism' and the narrative of identity that creates this solidarity as 'Mongolian Kazakhs' is constructed based on historic cultural narratives that have been reimagined in the post-socialist context. This narrative of Mongolian Kazakhness, as expressed through religiosity, kinship ties and linguistic versatility is further reinforced through place identities. While it is ultimately individual bodies that migrate, cultural mechanisms such as religiosity, kinship ties, and linguistic ability, can be important facilitators and inhibitors of migration. Place identity, in particular, ties individuals to particular places within Bayan-Ulgii, Mongolia; that is, for many Mongolian Kazakhs, a strong sense of place identity acts as a disincentive to permanent out-migration and an incentive to either remain in place or return to Mongolia.

As Willis et al. (2004) suggest, the importance of shared values and culture are an important component of socially constructed identities that don't necessarily conform to territorially bounded spaces. For Mongolian-Kazakhs these shared values have reemerged in the post-socialist period, helping to construct a narrative about place and identity that contradicts prescribed narratives of the Kazakh homeland and re-imagines a specific MongolianKazakh identity. This study contributes to a complex understanding of Kazakh identity that evolves over time and contains multiple layers of heterogeneity, including but not limited to the distinction between native-born Kazakhs and disaporic Kazakh groups, such as the Mongolian Kazakhs. However, Kazakhs choosing to remain in Mongolia are challenging the concept of a Kazakh homeland, and re-imagining their identities in relation to a shared history, culture and territorial or place-based definition. This Mongolian-Kazakh identity rewards immobility by placing value on place-based cultural practices and also creates a sense of belonging amongst a group which is not fully accepted in either Mongolia or in Kazakhstan.

\section{Role of funding sources}

None of the funding sources have played a role in study design; in the collection, analysis and interpretation of data; in the writing of the report; or in the decision to submit the article for publication.

\section{Acknowledgments}

This research was funded by the National Science Foundation BCS-0752411 and BCS-0752471, Association of American Geographers Research Grant, Wallace Travel and Research Grant from Macalester College, Stipendiary Fellowship from the Texas A\&M University Melbern G. Glasscock Center for Humanities Research; * International Research and Travel Grant from the Texas A\&M University Office of International Programs; * Women's Interdisciplinary Seed Grant Research Award from the Texas A\&M University Women's and Gender Studies Program, Texas A\&M University.

The authors would like to acknowledge the thoughtful and comprehensive suggestions offered by reviewers for this paper. Our paper is much stronger for your insights and recommendations. We would also like to sincerely thank those who have supported and assisted in our research in Mongolia, Celia Emmelhainz, Namara Brede, Amangul Shugatai, Nurshash Shugatai and the many others who helped at various stages of this project.

\section{References}

Abramson, D.M., Karimov, E.E., 2007. Sacred sites, profane ideologies: religious pilgrimage and the Uzbek state. In: Sahadeo, J., Zanca, R.G. (Eds.), Everyday Life in Central Asia: Past and Present. Indiana University Press, Bloomington, pp. 319-338.

Anderson, Benedict, 1983. Imagined Communities: Reflections on the Origin and Spread of Nationalism. Verso, London.

Asad, T., 2009. Thinking about religious belief and politics. Speech delivered at Macalester College, 23 October 2009.

Barcus, H.R., Brunn, Stanley D., 2010. Place elasticity: exploring a new conceptualization of mobility and place attachment in rural America. Geografiska Ann. B, Human Geograp. 92 (4), 281-295.

Barcus, Holly, Werner, Cynthia, 2010. The Kazakhs of Western Mongolia: transnational migration from 1990-2008. Asian Ethnic. 11 (2), 209-228.

Barcus, H.R., Werner, C.A., 2014. Transnational migration, local economic change, and the persistence and adaptation of rural livelihoods: a case study of the Kazakh Diaspora in Western Mongolia. In: Cawley, M., Bicalho, A.M.S.M., Laurens, L. (Eds.), The Sustainability of Rural Systems: Local and Global Challenges and Opportunities. Galway National University Press.

Bacon, Elizabeth, 1996. Central Asians Under Russian Rule: A Study in Culture Change. Cornell University Press, Ithaca, NY, 1996.

Bernard, H..Russell., 1996. Research Methods in Anthropology: Qualitative and Quantitative Approaches. Altamira Press, Lanham, MD.

Brede, Namara, 2010. Negotiating everyday islam after socialism: a study of the Kazakhs of Bayan-Ulgii, Mongolia. Unpublished Honors Thesis, Macalester College.

Brubaker, Rogers., 2002. Ethnicity without groups. Arch. Eur. Sociol 2 (XLIII), 163 189

Cerny, Astrid, 2010. Going where the grass is greener: China Kazaks and the Oralman immigration policy in Kazakhstan. Pastoralism 1 (1), 218-247.

Cohen, Robin, 1997. Global Diasporas: An Introduction. University of Washington Press, Seattle. 
Davé, Bhavna, 2007. Kazakhstan: Ethnicity, Language and Power. Routledge, New York.

Dawut, Rahile, 2009. Shrine Pilgrimage Among the Uighurs. Silk Road 6 (2), 56-67.

De Jong, G.F., 2000. Expectations, gender and norms in migration decision-making. Popul. Stud. 54, 307-319.

Diener, Alexander, 2006. Homeland as social construct: territorialization among Kazakhstan's Germans and Koreans. National. Paper: J. National. Ethnic. 34 (2), 201-235.

Diener, Alexander, 2009. One Homeland or Two? The Nationalization and Transnationalization of Mongolia's Kazakhs. Stanford University Press, Stanford, CA.

Diener, Alexander, 2014. Imagining Kazakhstani-stan: Considerations of Nationalizing Social Space and Socializing National Space. Paper presented at the 15th Annual Conference of the Central Eurasian Studies Society. Columbia University. New York. October 24-26.

Esenova, Saulesh, 2002. Soviet nationality, identity and ethnicity in central Asia: historic narratives and Kazakh ethnic identity. J. Muslim Minor. Affairs 22 (1), $11-38$.

ESRI. 10.1., 2011. ArcGIS. Environmental Systems Research Institute. ESRI Inc., Redlands, California.

Faist, Thomas, 2000a. The Volume and Dynamics of International Migration and Transnational Social Spaces. Oxford University Press, Oxford.

Faist, Thomas, 2000b. Transnationalism in international migration: implications for the study of citizenship and culture. Ethnic Racial Stud. 23 (2), 189-222.

Fierman, William, 2005. Kazakh Language and Prospects for Its Role in Kazakh 'Groupness'. Ab Imperio 2, 393-423.

Finke, Peter., 1999. The Kazakhs of Western Mongolia. In: Svanberg, Ingvar (Ed.), Contemporary Kazakhs: Cultural and Social Perspectives. Curzon Press, London, pp. 103-139.

Finke, Peter, 2003. Does privatization mean commoditisation? market exchange, barter, and gift giving in post-socialist Mongolia. In: Dannhaeuser, Norbert, Werner, Cynthia (Eds.), Anthropological Perspectives on Economic Development and Integration. Elsevier Press, Amsterdam, pp. 199-224.

Guilmoto, C.Z., Sandron, F., 2001. The internal dynamics of migration networks in developing countries. Popul.: English Selec. 13 (2), 135-164.

Harner, John, 2001. Place identity and copper mining in Sonora, Mexico. Ann. Assoc. Am. Geogr. 91 (4), 660-680.

Hereniko, Vilsoni, 1994. Representations of cultural identities. In: Howe, K.R., Kiste, Robert C., Lal, Brij V. (Eds.), Tides of History: The Pacific Islands in the Twentieth Century. University of Hawaii Press, Honolulu, pp. 406-434.

Hobsbawm, Eric, Ranger, Terence (Eds.), 1983. The Invention of Tradition. Cambridge University Press, Cambridge.

Jones, Reece, 2011. Dreaming of a golden bengal: discontinuities of place and identity in South Asia. Asian Stud. Rev. 35, 373-395.

Kaiser, Robert, 2000. Political Indigenization and Homeland-making in Russia's Republics. The National Council for Eurasian and East European Research, Washington, DC.

Kaiser, Robert, Nikiforova, Elena, 2007. Borderland spaces of identification and dis/ location: multiscalar narratives and enactments of Seto identity and place in the Estonian-Russian borderlands. Ethnic Racial Stud. 29 (5), 928-958.

Koch, Natalie, 2014. 'Cowboys', 'Hooligans', and Country 'Bumpkins': Constructing the 'Other' in Kazakhstan's Texas. Paper presented at the 15th Annual Conference of the Central Eurasian Studies Society. Columbia University. New York. October 24-26.

Kusçu Bonnenfant, Işik, 2012. Constructing the homeland: Kazakhstan's discourse and policies surrounding its ethnic return-migration policy. Central Asian Surv. 31 (1), 31-44.

Kusçu, Işik, 2013. Ethnic return migration and public debate: The case of Kazakhstan. International Migration. Blackwell, IOM.

Lillis, Joanna, 2014. Kazakhstan: Astana Entices Kazakhs from Abroad Amid Ukraine Crisis. Eurasianet.org. July 14, 2014. <http://www.eurasianet.org/node/69006> (accessed 05.08.14)

Louw, M., 2006. Pursuing 'Muslimness:' Shrines as sites for moralities in the making in post-Soviet Bukhara. Central Asian Surv. 25 (3), 319-339.
Massey, D.S., Arango, J., Hugo, G., Kouaouci, A., Pellegrino, A., Taylor, J.E., 1993. Theories of international migration: a review and appraisal. Popul. Dev. Rev. 19 (3), 431-466.

McHugh, Kevin E., 2000. Inside, outside, upside down, backward, forward, round and round: a case for ethnographic studies in migration. Prog. Hum. Geogr. 24, 71-89.

Milligan, Melinda J., 1998. Interactional past and potential: the social construction of place attachment. Symbol. Interact. 21, 1-33.

NSOM (National Statistical Office of Mongolia). 2001. 2000 Population and Housing Census: The Main Results. Ulaanbaatar.

NSOM (National Statistical Office of Mongolia). 2003. Mongolian Population in XX Century. Ulaanbaatar.

Pessar, Patricia R., Mahler, Sarah J., 2003. Transnational migration: bringing gender in. Int. Migr. Rev. 37 (3), 812-846.

Portisch, A.O., 2006. Kazakh domestic crafts production in Western Mongolia: everyday relevance and meaning. Paper presented at CESS 7th Annual Conference, Ann Arbor, MI.

Privratsky, B.G., 2001. Muslim Turkistan: Kazak Religion and Collective Memory Curzon Press, Richmond, Surrey.

Proshansky, Harold M., Fabian, Abbe K., Kamiknoff, Robert, 1983. Place identity: physical world socialization of the self. J. Environ. Psychol. 3, 57-83.

Reid, Anthony, 2010. Nationalism in Asia. In: Imperial Alchemy: Nationalism and Political Identity in Southeast Asia. Cambridge University Press, Cambridge and New York, pp. 1-24.

Relph, E., 1976. Place and Placelessness. Pion Limited, London.

Ro'i, Y., Wainer, A., 2009. Muslim identity and Islamic practice in post-Soviet Central Asia. Central Asian Surv. 28 (3), 303-322.

Schatz, Edward, 2000. The Politics of multiple identities: lineage and ethnicity in Kazakhstan. Europe-Asia Stud. 52 (3), 489-506.

Schatz, Edward, 2004. Modern Clan Politics: The Power of 'Blood' in Kazakhstan and Beyond. University of Washington Press.

Schensul, Steven L., Schensul, Jean J., LeCompte, Margaret D., 1999. Essentia Ethnographic Methods: Observations, Interviews and Questionnaires. Altamira Press, Lanham, MD.

Schwab, Wendell, 2011. Establishing an Islamic niche in Kazakhstan: Musylman Publishing House and Its Publications. Central Asian Surv. 25 (3), 319-339.

Somers, Margaret R., 1994. The narrative constitution of identity: a relational and network approach. Theory Soc. 23 (5), 605-649.

SPSS. 2008. SPSS Statistics 17.0. Polar Engineering and Consulting.

Tsuda, Takeyuki, 2009. Conclusions: diasporic homecomings and ambivalent encounters with the Ethnic Homeland. In: Tsuda, Takeyuki (Ed.), Diasporic Homecomings: Ethnic Return Migration in Comparative Perspective. Stanford University Press, California, pp. 325-350.

Tuan, Yi-Fu, 1980. Rootedness verses sense of place. Landscape 24, 3-8.

Tuan, Y.-F., 1996. Cosmos and Hearth: A Cosmopolite's Viewpoint. University of Minnesota Press, Minneapolis, MN.

United Nations Development Programme Kazakhstan (UNDP), 2006. Status of the Oralmans in Kazakhstan: Overview. Almaty, Kazakhstan.

Werner, Cynthia, Barcus, Holly, 2009. Mobility and immobility in a transnationa context: changing views of migration among the Kazakh Diaspora in Mongolia. Migration Lett. 6 (1), 49-62.

Werner, Cynthia, 1997. Household networks and the security of mutual indebtedness in Rural Kazakhstan. Central Asian Surv. 17 (4), 597-612.

White, S.E., 1983. Return migration to Appalachian Kentucky: an atypical case of nonmetropolitan migration reversal. Rural Sociol. 48 (3), 471-491.

White, S.E., 1989. America's Soweto: population redistribution in Appalachian Kentucky: 1940-1986. Appal. J. 16 (4), 350-360.

White, S.E., Brunn, S.D., 1994. The persistence of social isolation in Eastern Kentucky: an examination of marriage-mate selection distances. Southeastern Geograp. 34 (1), 1-16.

Willis, Katie, Yeoh, Brenda S.A. Abdul Khader Fakhri, S.M. 2004 Transnationalism as a challenge to the nation. In: Yeoh, Brenda S.A., Willis, Katie (Eds.), State Nation/Transnation: Perspectives on Transnationalism in the Asia-Pacific Routledge, London and New York, pp. 1-16. 